\title{
ウリ科植物成分に関する研究
}

\author{
笠井良次
}

\section{Studies on the Constituents of Cucurbitaceous Plants}

\author{
Ryoji KASAI \\ Faculty of Pharmaceutical Sciences, Hiroshima International University, \\ 5-1-1 Koshingai, Hiro, Kure City 737-0112, Japan
}

(Received April 11, 2008)

\begin{abstract}
I have an opportunity to have co-operative studies with Chinese group of Kunming Institute of Botany. Since then, I have investigated the chemical constituents of a number of Chinese plants of Araliaceae, Umbelliferae, Labiatae, $\mathrm{Cu}-$ curbitaceae and other families. This review describes the structural elucidation of the cucurbitane, oleanane and dammarane glycosides, and their biological activities under the joint studies on cucurbitaceous plants, Bolbostemma, Hemsleya, Siraitia and Neoalsomitra species. New oleanane glycosides having novel cyclic structure were isolated from $\mathrm{Bol}$ bostemma paniculatum. The potent solubilizing effect of these compounds was investigated. A number of cucurbitane glycosides were isolated from Hemsleya carnosiflora, H. panacis-scandens, Siraitia grosvenorii and S. siamensis. Some of these glycosides taste sweet, bitter or tasteless. The structure-taste relationships of the glycosides of a 3- $\alpha$-hydroxycucurbit-5-ene-type triterpene have been discussed. Anti-tumor-promotion effects as well as the ecdysteroid agonist and antagonist activities of these cucurbitane glycosides were investigated. New dammarane glycosides were isolated from Neoalsomitra integrifoliola.
\end{abstract}

Key words_ _ cucurbitaceae; triterpene glycoside; structure-taste relationship; solubilizing effect

\section{1. はじめに}

ウリ科植物に関する中国科学院昆明植物研究所と の共同研究の機会に恵まれ，以来，約 20 年に亘り Hemsleya 属, Bolbostemma 属, Neoalsomitra 属, Siraitia 属, Trichosanthes 属植物に関する研究を行 ってきた。これらの配糖体成分についての構造研 究，さらに，それらの生物活性あるいは物理的性質 を検討した結果について記述する.

2. 生薬土貝母のサイクリックビスデスモシド

土貝母は, 中国産植物假貝母 [Bolbostemma paniculatum (Maxim.) Franquet] の塊茎由来の生薬 で，抗炎症薬あるいは毒蛇に咬まれたときの解毒薬 として使用されている。中国産ウリ科植物の成分研 究の一環として, 本生薬のメタノールエキスについ て研究を行い, 天然配糖体としては稀な大環状構造

広島国際大学薬学部生薬学教室（干737-0112 呉市広古 新開 5-1-1)

e-mail: r-kasai@ps.hirokoku-u.ac.jp

本総説は, 平成 19 年度退職にあたり在職中の業績を中

心に記述されたものである。
を持つオレアナン系配糖体類を単離し，これら化合 物には水に難溶な物質に対する溶解促進作用のある ことを明らかにした。ここでの溶解促進作用という 用語には，水に全く溶けない物質に対する可溶化の 意味も含まれる。

\section{2-1. 単離と構造決定 メタノールエキスのダ} イヤイオン HP-20 カラムクロマトグラフィーによ り得られたメタノール溶出画分（粗配糖体）を各種 カラムクロマトグラフィーを繰り返すことにより 3 種の新規化合物を得た。このうち 2 種は, 順相系あ るいは逆相系シリカゲルクロマトグラフィーのいず れの場合でも互いに分離不能であったが，最終的に はヒドロキシアパタイトのクロマトグラフィーによ り分離に成功した。その当時, 旭光学秼で開発され たばかりのクロマト用球状ヒドロキシアパタイトを 試験用サンプルとして提供を受けたお陰である。人 参サポニン, ステビアの甘味配糖体の分析について も旭光学侏株式会社との共同研究を行い良好な結果 を得ている. ${ }^{1)}$ メタノール・水あるいはアセトニト リル・水など単純な溶媒系を使用することが可能 
で，ほぼ順相モードで溶出してくる，ただし，酸性 の配糖体（サポニン）は吸着されて，ほとんど溶出 しないのが欠点である. 分離機構については不明で ある。もっぱらタンパク質や核酸の分離に用いられ ているヒドロキシアパタイトは，低分子の配糖体の 場合でも大いに利用することができる。順相系ある いは逆相系シリカゲルで分離不能な場合に試してみ る価值がある。

このように，土貝母から tubeimoside I （1)，II （2），III（3）と命名した 3 種の配糖体を単離し，そ れぞれの構造を Fig. 1 のように決定した. ${ }^{2,3)}$ 糖鎖が 3-ヒドロキシ-3-メチルグルタール酸のエステル結合 を介して架橋された大環状構造を持つオレアナン系 トリテルペンのビスデスモシドである。われわれ は，このような化合物をサイクリックビスデスモシ ドと命名した。構造決定の初期の段階において，ア

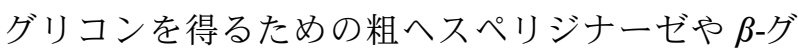
ルコシダーゼなどによる酵素分解を試みたが，加水 分解はほとんど進行しなかった．結果的には，この ことが tubeimoside 類の環状構造を推定するための
よいヒントになった.

最後に, アシル部分の絶対配置の決定について述 ベる、3-ヒドロキシ-3-メチルグルタール酸そのもの はキラリテイーを持たない。しかし，化合物 1-3 の ようにエステル結合した場合には，その 3 位にキラ リテイーが生ずる．化合物 $\mathbf{1}$ を例に，この立体配置 の決定について説明する．まず，弱いアルカリで処 理してハーフエステル体 4 とし，次に糖部などの水 酸基をアセチル化し，3-ヒドロキシ-3-メチルグル タール酸部分の一方の遊離のカルボキシル基をジボ ランで還元してアルコール体とし，アルカリ加水分 解で得られたメバロン酸の GC-MS の結果から 3-Sメバロン酸と同定した。この GC-MS によるメバロ ン酸の絶対配置の決定は，平井らの HPLC による 方法4)を一部変更して行った. Tubeimoside I (1) のアシル部の 3 位の立体配置を Fig. 1 に示すよう に決定した。

2-2. サイクリックビスデスモシドの溶解促進作 用 天然物質の単離の実験で，精製が進むにつれ て目指す物質の溶解度が低下することにしばしば遭
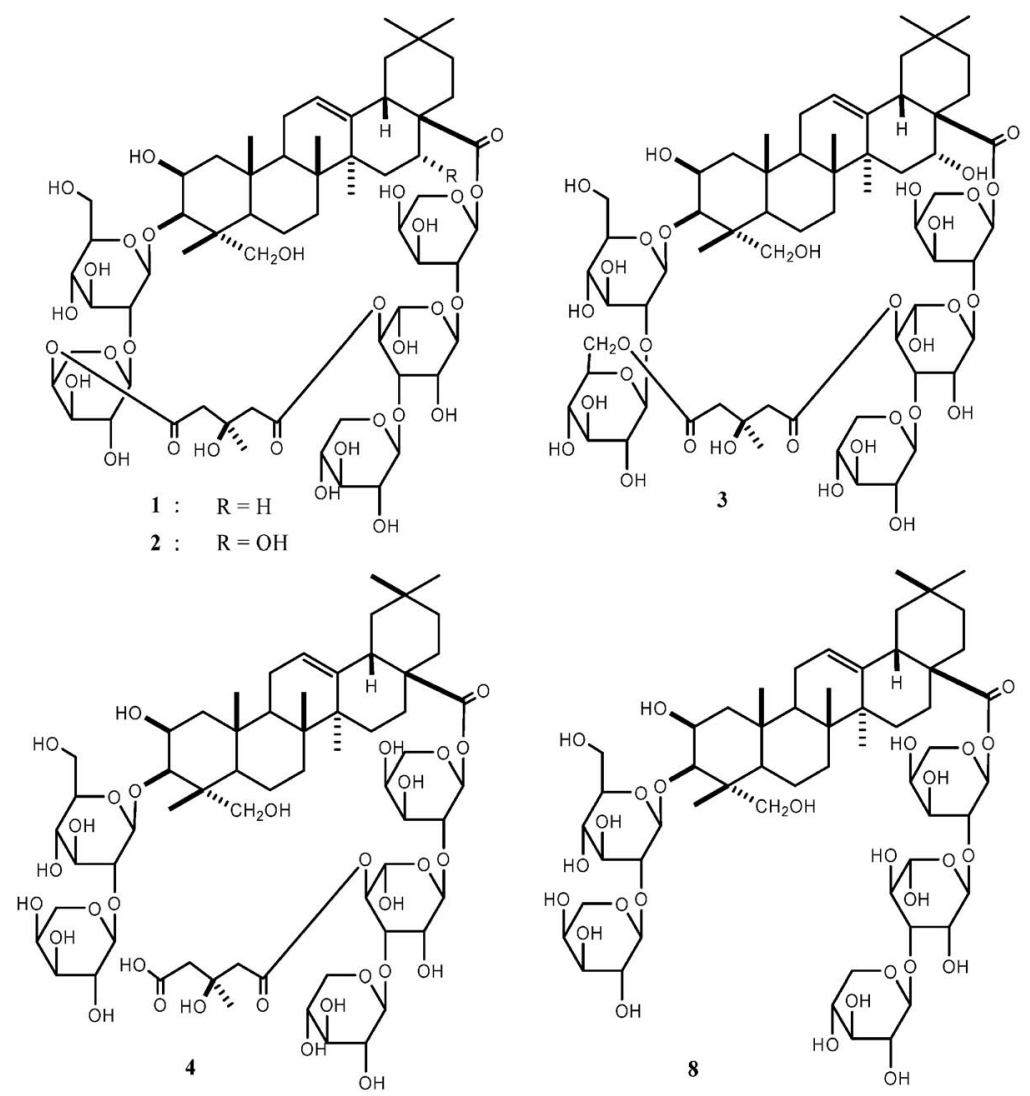

Fig. 1. 
遇する．これは，抽出など初期の過程で共存してい る界面活性物質が除かれていくことに起因するもの であろうか．例えば，サポニン類あるいはその他の 配糖体類もこの界面活性物質に相当するものと思わ れる，筆者らは，配糖体類の界面活性剂としての生 薬薬剤化学的意義を検討するために, 延命皮のビス

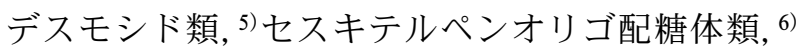
人参の ginsenoside Ro（5）（= chikusetsusaponin$\mathrm{V})$, ${ }^{7)}$ 甘草の glycyrrhizin $(\mathbf{6})^{8)}$ などの溶解促進作用 に焦点を当てて研究を行ってきた.

本稿では, これらの研究の一環として行った tubeimoside 類の溶解促進作用について解説する.

土貝母から得られた tubeimoside I（1)，II（2）, III (3) の Yellow OB と $d l$ - $\alpha$-tocopherol に対する溶

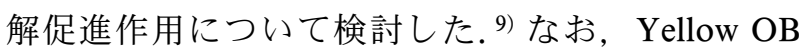
は界面活性作用の試験によく用いられる物質で, $d l$ - $\alpha$-tocopherol と同様に水に全く溶解しない脂溶 性色素である.

まず，Yellow OB に対するリン酸緩衝液中での 溶解促進作用の結果を述べる。合成界面活性剂 Tween 20, さらに以前の実験で溶解促進作用を認 めた延命皮のサポニン mukurozisaponin Y2 (7) ${ }^{5)}$ 及び glycyrrhizin (6) ${ }^{8)}$ とともに比較検討した。化 合物 1-3 の $1.0 \mathrm{mmol} / 1$ 水溶液では, Tween 20 の場 合の半分程度ではあるが， 7 よりも強い溶解促進能 を示した。一方，アルカリ加水分解によりアシル架 橋を除いたデアシル体 8 （Fig. 1）では低下した.

次に，化合物 $\mathbf{1}$ 及び $\mathbf{8}$ の各濃度での $d l-\alpha$ tocopherol に対する溶解促進作用実験の結果につい て述べる．両者とも濃度を増加させるにつれ $d l-\alpha-$ tocopherol に対する溶解促進能は上昇するが，1の ほうが圧倒的に強い作用を示した。したがって，溶 解促進作用における大環状構造の関与は明らかであ る. Ttubeimoside 類の溶解促進作用の機構を解明 するためにつぎのような検討を行つた.

\section{2-3. 溶解促進作用機構の解明9)}

2-3-1. 臨界ミセル形成濃度（cmc） Figure 2 に tubeimoside I （1）及びそのデアシル体 8 の濃度 と表面張力の関係を示した。屈折点から求めたそれ ぞれの臨界ミセル形成濃度 (critical micelle concentration, cmc）は 1 が $0.001 \%, 8$ が $0.011 \%$ でっ た. なお，これまでのわれわれの実験で溶解促進作 用が認められているサポニン類では ginsenoside Ro

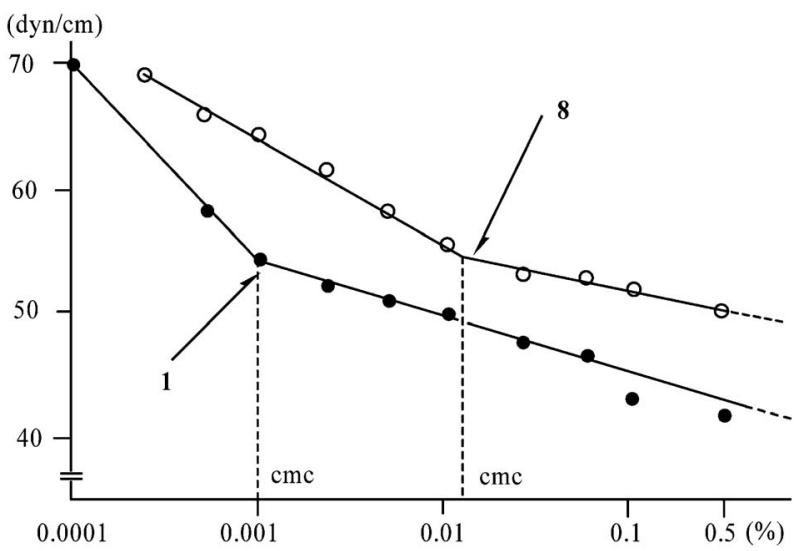

Fig. 2. Surface Tension of $\mathbf{1}$ and $\mathbf{8}$ in Aqueous Solution

(5) の $\mathrm{cmc}$ は $0.001 \%$ ，その他のサポニン類は 0.010.006\%である。このように，8 は他のサポニンと ほぼ同程度であるが，1 は極めて低い $\mathrm{cmc}$ の值を示 した。一般に cmc の小さい非イオン性の界面活性 剤は優れた界面活性を持ち，その効果はイオン性の ものより優れていることが知られており，19優れ た溶解促進能も，その小さな $\mathrm{cmc}$ に由来するもの と思われる.

\section{2-3-2. ミセルの平均分子量, ミセルの半径}

Tubeimoside 類の溶解促進作用がミセル形成に よるものであれば，このミセルは，どのようなもの か, Debye の理論に従い光散乱データの Zimm plot からミセルの平均分子量及び慣性半径を求めた. ${ }^{10)}$ その結果, tubeimoside I (1) は, 単独で平均分子 量 16 万を示すことから，平均 120 個の分子で 1 個 のミセルを形成していることが判明した。ミセルは 低濃度（10\%以下）では均質な球形と考えられてお り, この場合, 半径 $1500 \AA$ の球形であると推定さ れた。デアシル体 8 は，平均 50 分子で 1 個のミセ ルを形成し，半径 $1000 \AA$ であった。

延命皮から得られる saponin A（9）は, ${ }^{11 ）}$ 水に対 する溶解度が極めて低いサポニンであるが，tubeimoside 類の添加により 9 の溶解度が著しく増加す る. Tubeimoside I (1) と9の濃度比が $1: 1$ のと き, ミセルの平均分子量は $\mathbf{1}$ が単独のときと同程度 の 15 万を示すが, 濃度比 $1: 2,1: 5$ と9 が過剰の ときは約 4.5 倍の 60 万を示した.

したがって1は，ある一定量以下の 9 の存在下で は，これを自身のミセルに取り込み，一方，過剩な 9 の存在下では不安定な 9 のミセルに自らが入り込 
みミセルを安定化させるものと推定される.

\section{Hemsleya 属植物の研究}

Hemsleya 属植物は, 中国西南部からべトナム, インドの比較的暖かい地方に分布しており，これま でに約 30 種が知られている. ${ }^{12)}$ 日本に生育するウ リ科植物の中で, 分類上, 本属に最も近い植物はア マチャヅル (Gynostemma pentaphyllum) である. 中国雲南省の少数民族は Hemsleya 属植物の塊茎を 抗菌，抗炎症の薬として用いている. ${ }^{12)}$

3-1. 肉花雪胆 (Hemsleya carnosiflora C. Y. Wu et C. L. Chen）及び藤三七雪胆（H. panacis-scandens C. Y. Wu et C. L. Chen) の配糖体成分 肉 花雪胆及び藤三七雪胆の塊茎エタノール抽出物の配 糖体画分を各種クロマトグラフィーにより単離・精 製を行い，肉花雪胆から carnosifloside I -VI（1015）と命名した 6 種のククルビタン系トリテルペン 配糖体, ${ }^{13)}$ 藤三七雪胆から 10，12，14，15 並びに scandenoside R1-R6（16-21）と命名した 10 種の配 糖体を得た (Fig. 3). ${ }^{14)}$ 肉花雪胆と藤三七雪胆は形 態的に酷似しており両者の見分けが難しいとされて いたが，ケモタキソノミーの面から両者を容易に区 別できることが明らかとなった。

ククルビタン系トリテルペノイド（ククルビタシ ン類）は一般に強い苦味を示し，中にはがん細胞に 対し強い細胞毒性を示すものもあり，抗がん剂の開 発につながるものとして注目されている。，一方，羅 漢果の mogroside 類や, ${ }^{15-17)}$ Bryonia dioica の bryodulcoside $\mathrm{e}^{18-20)}$ など甘味を示すククルビタン系トリ テルペンの配糖体も知られている.

ここで単離した carnosifloside 類 $(\mathbf{1 0}-\mathbf{1 5})$ と scandenoside 類（16-21）は，呈味の種類にしたが って次のように分類することができる.

化合物 14，15，21 は甘味を示すものである. Figure 3 の括弧の中の数值はショ糖の甘味を 1 とし たときのそれぞれの化合物の甘味倍数である。いず れもアグリコンの 11 位に $\alpha$-水酸基が存在する. 化 合物 11-13，20 は苦味を示すものである。.いずれも 11 位にケトンがあり，甘味を示す化合物の11-オキ ソ体に相当する。例えば，甘味を示す carnosifloside VI（15）の11-オキソ体が carnosifloside III（= 11-oxocarnosifloside VI， 12) である。化合物 10, 16-19 は無味である.

3-1-1. ククルビタン系トリテルペン配糖体の味
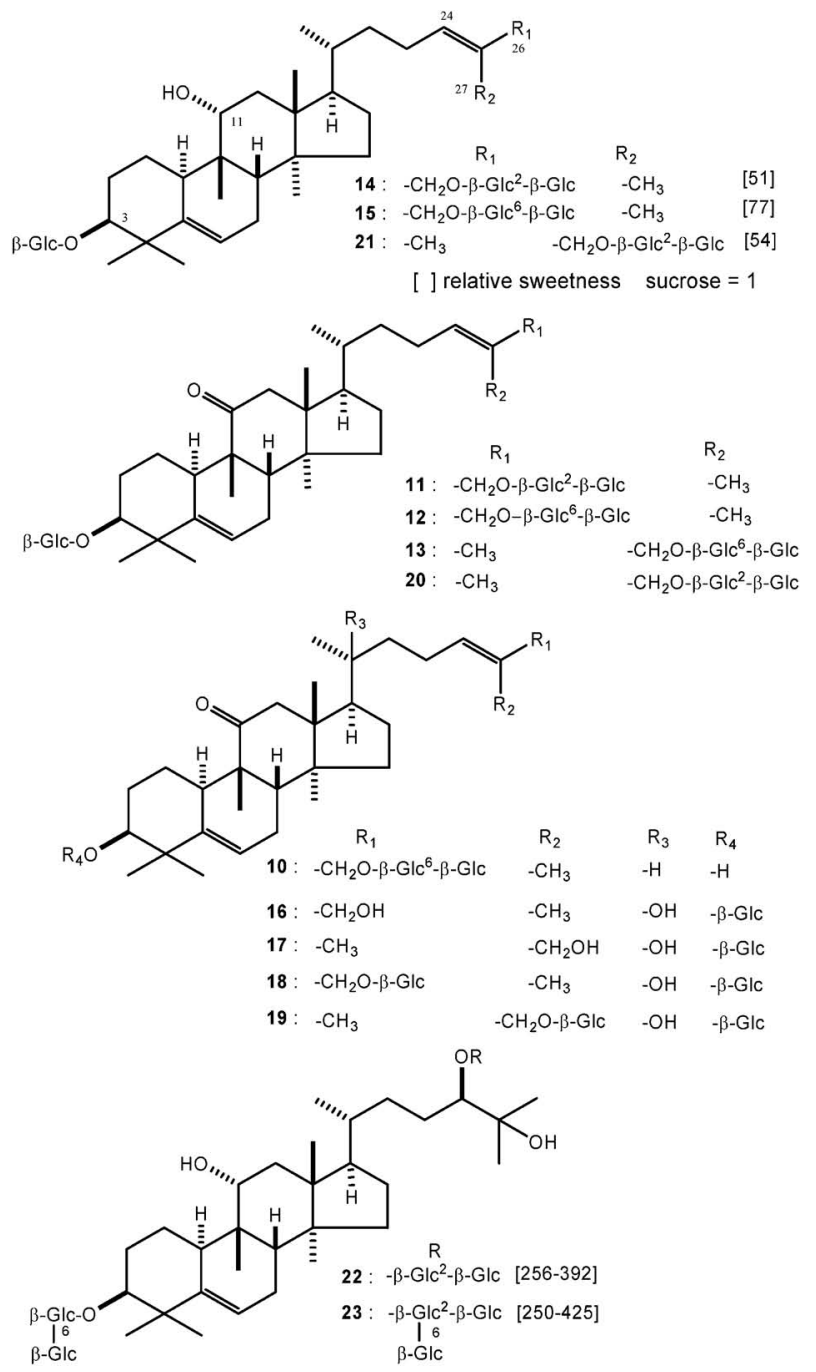

Fig. 3.

と構造の関係 ウリ科植物の羅漢果の mogroside IV（22）とV（23）（Fig. 3）15-17）はいずれもアグリ コンの側鎖にグリコール構造を持つ高甘味度の化合 物である。このグリコール構造に着目し，苦味を示 す11-ケト体である carnosifloside III（12）を四酸化 オスミウムで酸化し，側鎖の 24 位と 25 位に水酸基 を導入した混合物 24 を得た（Chart 1)，24 は甘味 を示した。次に甘味を示す carnosifloside VI（15） の甘味がどのように変化するか同様の実験を行い混 合物 25 を得た。しかし，25 は甘味を示すが，15よ りも甘味倍数が低下した。なお， 15 の側鎖の二重 結合を還元した化合物 $\mathbf{2 6}$ は無味であった (Chart 2).

化合物 15 の 11 位 $\alpha$ - 水酸基を $\beta$-水酸基に変換す ればごうなるか，Chart 2 のように carnosifloside III （12）の 11 位のカルボニルを $\mathrm{NaBH}_{4}$ で還元し，11 

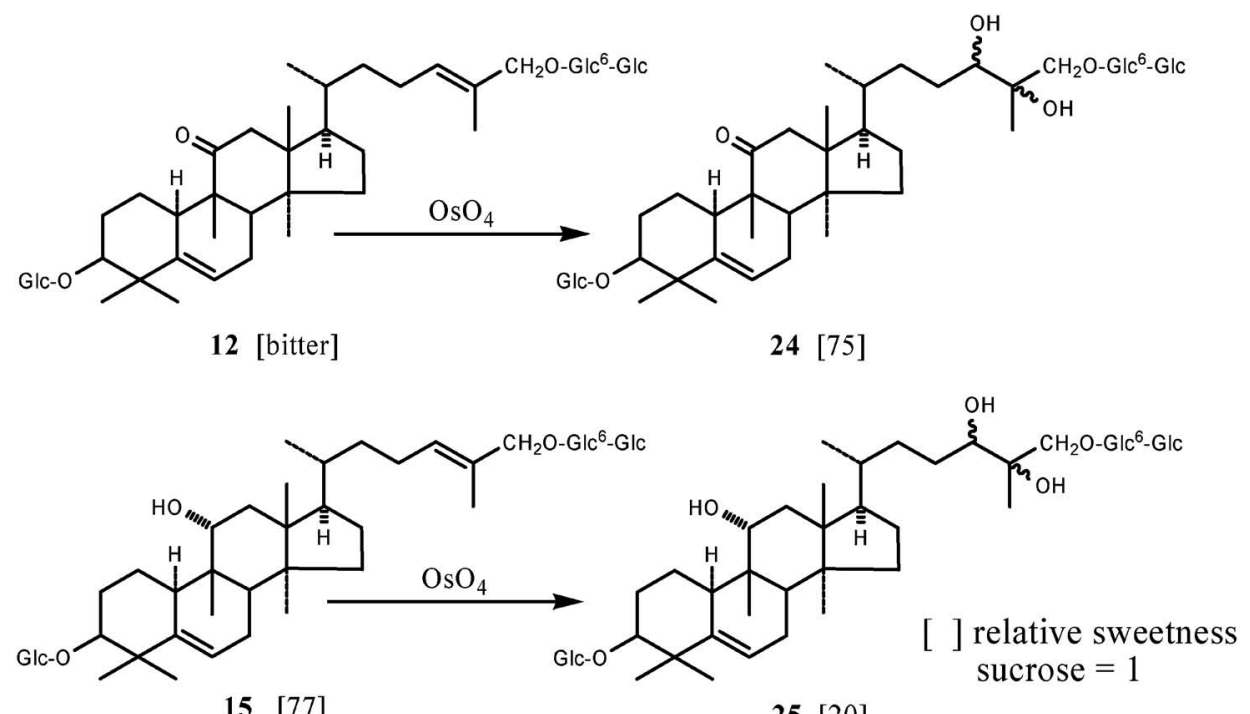

15 [77]

25 [20]

Chart 1.

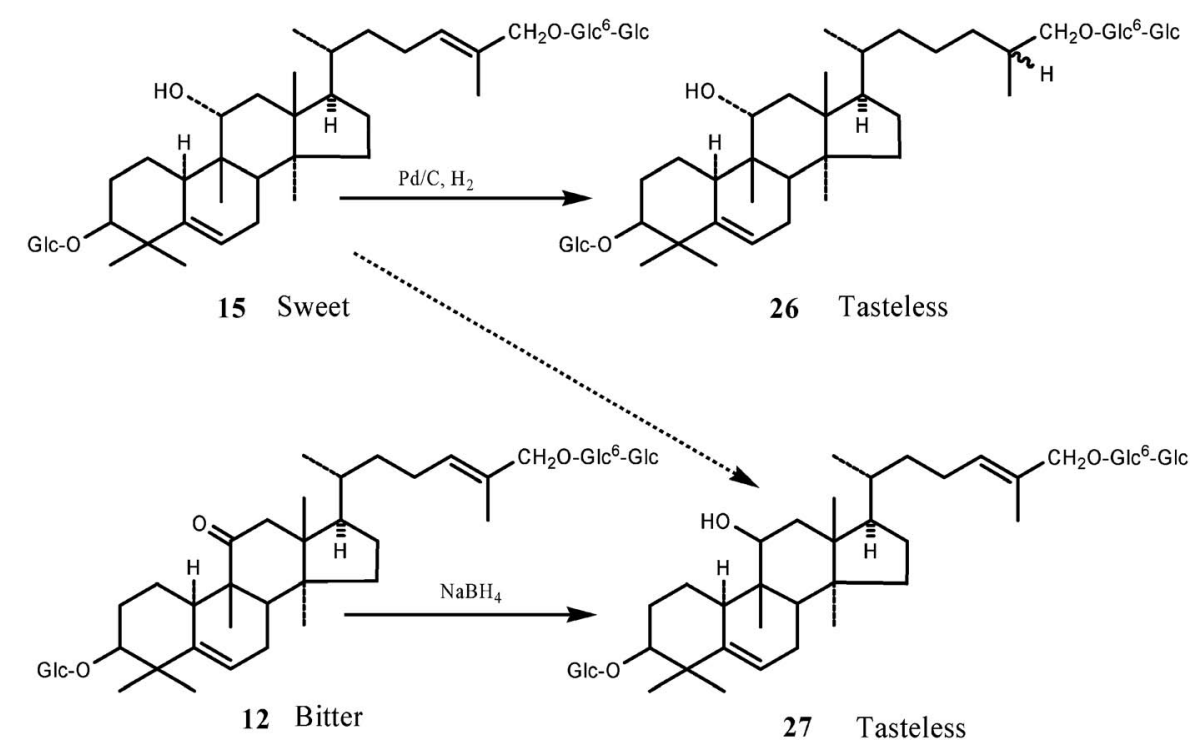

Chart 2.

位 $\beta$-水酸基の化合物 $\mathbf{2 7}$ としたが，このものは無味 であった。したがって，高甘味物質の carnosifloside VI（15）の 11 位の $\alpha$-水酸基が $\beta$-水酸基に変化 すると全く味を示さなくなる.

ククルビタン系トリテルペン配糖体の味（甘味, 苦味, 無味) と化学構造との関係を明らかとするた めには，さらなる検討が必要である。少ない例であ るが，以上の結果をまとめてみると以下のようにな る.

1） 甘味又は苦味を示すものは，アグリコンの両 端，つまり，この場合は 3 位と 26 位又は 27 位に糖
が結合している．また，全体として 3 分子以上の単 糖類が結合し，一端には少なくとも 2 個以上の単糖 類が結合している。しかし，後述する mogroside III（28）の場合は 3 分子の糖が結合しているが無味 である. ${ }^{21)}$

2）アグリコンの 11 位における酸素官能基の種 類又は配置により味が決定される。つまり， $\alpha$-水酸 基の場合は甘味，ケト基の場合は苦味， $\beta$-水酸基の 場合は無味となる。

3）側鎖の二重結合を酸化してグリコールとする と，苦いものは甘味を示すようになるが，本来甘い 
ものは逆に甘味倍数が低下する。側鎖の二重結合を 還元すると甘味は消失する。なお，側鎖二重結合の シスートランスは味にはなんら影響を与えない.

以上，本系統化合物の甘味を中心とした味と構造 の関係について述べたが，一般にククルビタン系化 合物は毒性を持つことで知られるため，これらを甘 味料として用いる場合の毒性が問題となる．Figure 4 に 3 種のククルビタン系化合物の毒性を示し

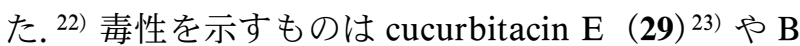
(30) ${ }^{24)}$ などのように高度に酸化された構造を持 ち，特に $\alpha, \beta$ 不飽和ケトン構造が関与するものと されている。，一方，このような部分構造を持たない bryogenin (31) ${ }^{25)}$ は $400 \mathrm{mg} / \mathrm{kg}$ でも急性毒性を示さ ない。したがって, carnosifloside 類や scandenoside 類も化学構造の上からは $\mathbf{3 1}$ と同様に少なくと も急性毒性を持たない安全な物質と考えられる.

\section{3-1-2. Scandenoside 類, carnosifloside 類の抗発} がんプロモーター活性26)

最初に scandenoside 類と carnosifloside 類について, Epstein-Barr ウイ ルスを利用したスクリーニングを行った．強い活性 が認められた scandenoside R6（21）について，マ ウスを用いた抗発がんプロモーター活性を検討し た. 発がん物質は dimethyl-benzanthracene(DMBA), 発がんプロモーターは 12-O-tetradecanoylphorbol13-acetate（TPA）を用いた。 1 週間に 2 回ずつこ れらを皮膚に塗布，これを 20 週間続けた。腫瘍の 生じたマウスの数と 1 匹当たりの腫瘍の数で判定し た。その結果 scandenoside R6（21）には，TPAに
よる発がん促進作用を抑制する効果のあることが判 明した。

3-1-3. 昆虫変態ホルモン拮抗作用 ${ }^{27)}$ キイロ ショウジョウバエから調製した $\mathrm{B}_{\mathrm{II}}$ 細胞を用いて, carnosifloside II （11），VI（15）及び carnosifloside 類のアグリコン carnosiflogenin A (32), B (33), C (34), ククルビタシン類の 23,24-dihydrocucurbitacin F (35), 25-acetoxy-23,24-dihydrocucurbitacin F（36）（Fig. 5）の昆虫変態ホルモン受容体に 対する作用について検討した。

マイクロプレートに各種濃度のサンプルのメタ ノール溶液を入れ，昆虫変態ホルモン，この場合 20-hydroxyecdysone を加え，いったん乾固する。 次に $\mathrm{B}_{\mathrm{II}}$ 細胞を加え， 7 日間培養する。 $\mathrm{B}_{\mathrm{II}}$ 細胞はプ レート上で生育し，污濁度として検出することがで きる. 吸光度を測定し，コントロールに対して吸光 度が上昇するとアンタゴニスト，低下するとアゴニ ストとして判定する。位相差顕微鏡で細胞の大き さ，形態などを観察する．5 種の化合物 32-36 はい ずれも吸光度を増加させ，昆虫変態ホルモンに対す るアンタゴニストとしての活性を示した。

3-1-4. 藤三七雪胆の配糖体成分 (再検索) ${ }^{28)}$ 藤三七雪胆の配糖体成分に関する再検索を行い, 化合物 37-41の5 種の成分を単離，構造決定した (Fig. 6).これらのうち, 38 の構造で示されるもの は，既に Persea mexicana の苦味成分である per-

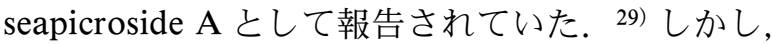
両者の比旋光度の值は一致せず，さらに報告されて

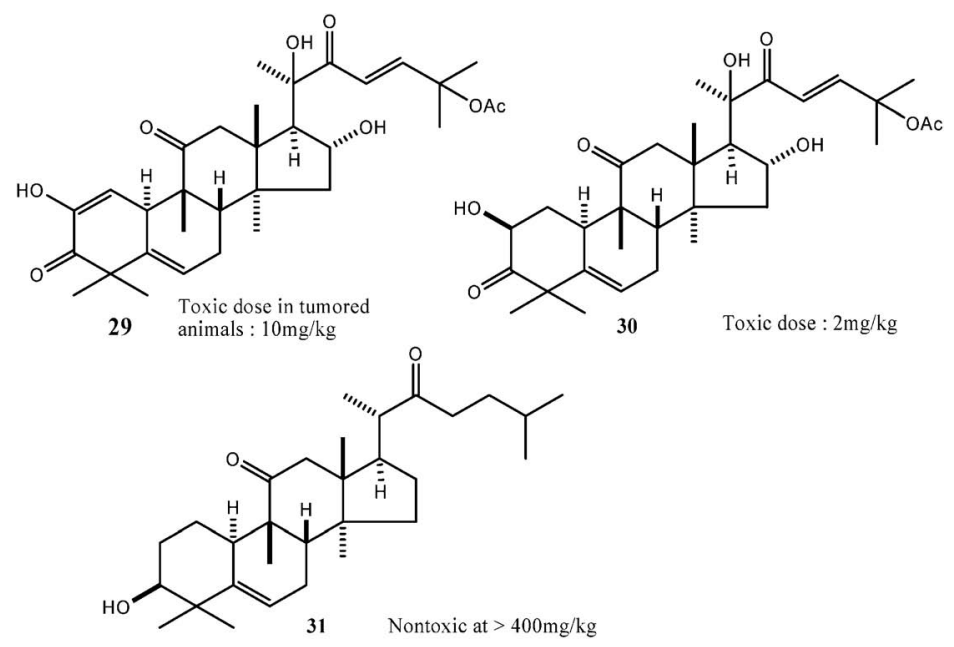

Fig. 4. Toxicity of Cucurbitane Triterpenoids 29-31 


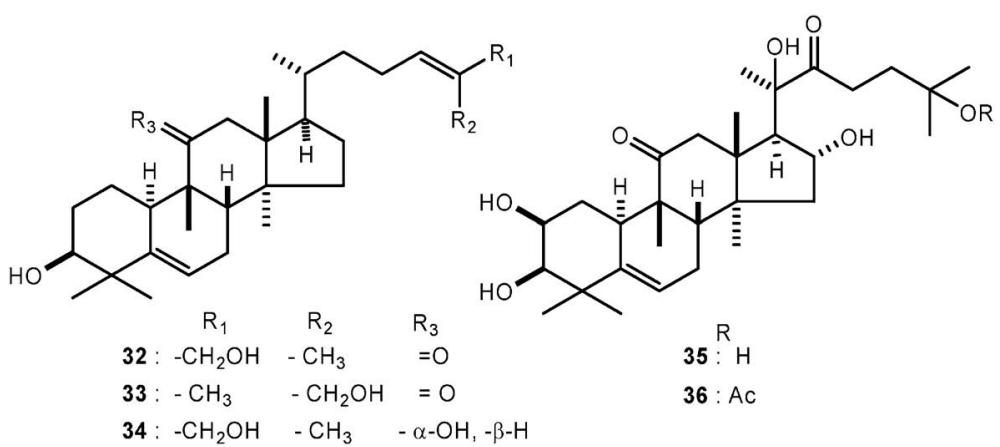

Fig. 5.
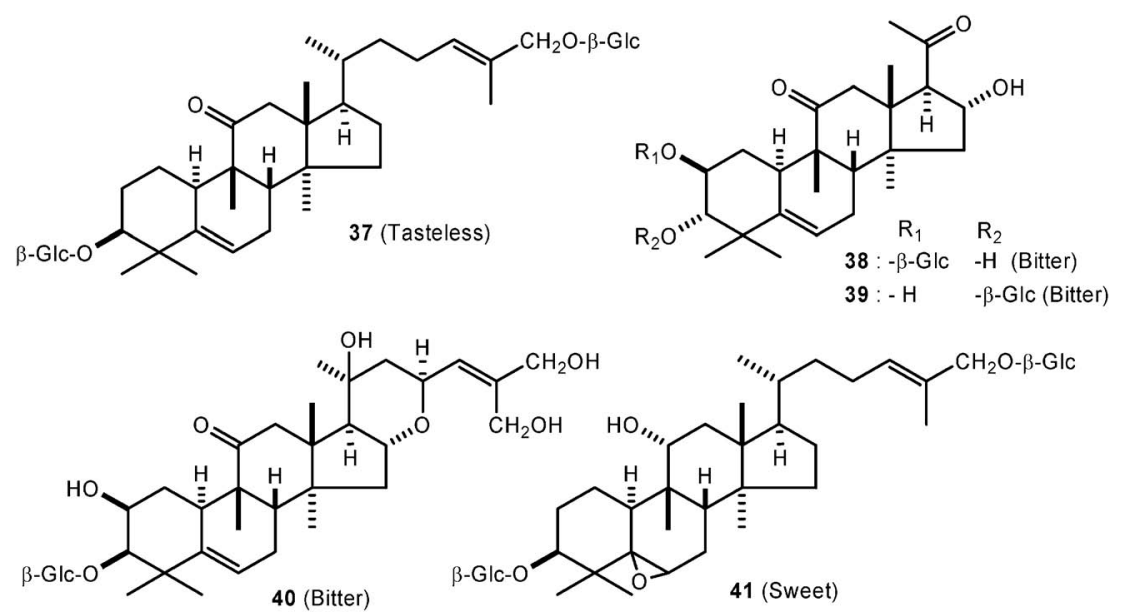

Fig. 6.

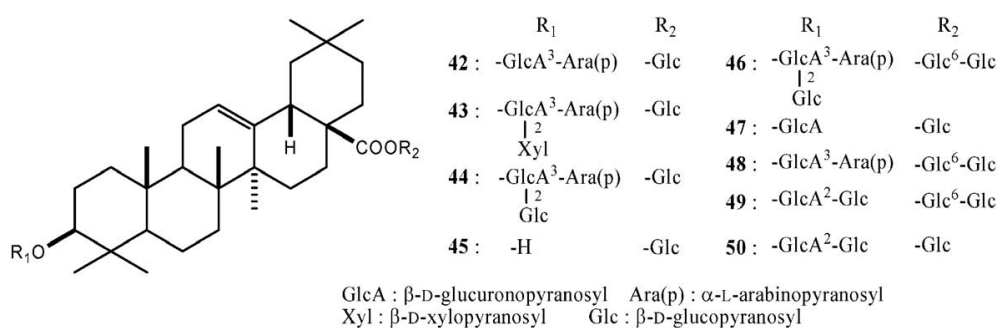

Fig. 7.

いる ${ }^{1} \mathrm{H}$ 並びに ${ }^{13} \mathrm{C}-\mathrm{NMR}$ スペクトルデータではそ の構造を説明できず，これらのデータは，むしろ 39 のデータと一致していた。したがって, perseapicroside A の構造を 38 のように訂正するとと もに, perseapicroside A として報告されている構造 に相当するものは 39 であると結論した。 以上，新 規化合物を scandenoside R8（37），R9（38）， R10 (40)，R11（41）と命名した。化合物 37 は無味, 38，39，40 は苦味，41 は甘味を示した。化合物 41 は量が少なかったため, 甘味倍数の測定を行ってい
ない.

3-2. 羅鍋底 (H. macrosperma C. Y. Wu ex C. Y. Wu et C. L. Chen), 中華雪胆 ( $H$. chinensis Cogn. ex Forbes et Hemsl.), 馬銅鈴雪胆 $(\boldsymbol{H}$. graciliflora（Harms）Cogn.）の配糖体成分羅鍋 底から hemsloside Ma1 (42), Ma2 (43), Ma3 （44）と命名した 3 種のオレアノール酸をアグリコ ンとする配糖体を単離, 構造決定するとともに $\beta$ glucosyl oleanolate（45）を単離・同定した（Fig. 7). 30) 中華雪胆からは新規の配糖体 hemsloside H1 
（46）を単離・構造決定し， 42, 44, 45, chikusetsusaponin-IVa（47）を単離・同定した. ${ }^{30)}$

馬銅鈴雪胆からは，新規の配糖体 hemsloside G1 (48), G2（49）を単離・構造決定し，42，44，45, 46, chikusetsusaponin- $\mathrm{V}(\mathbf{5 0})$ を単離・同定し

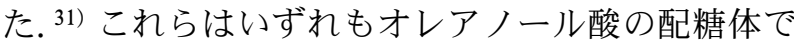
ある。これらの配糖体は比較的高い収量で得られ， さらに, 1 株当たりの塊茎の重量はキログラムの単 位であり，大きいものでは 10 数キログラムに及ぶ ものもある。したがって，これらの植物はオレア ノール酸を得るための資源として有用であると考え ている.

\section{Siraitia 属植物の配糖体成分}

Siraitia grosvenorii (Swingle) C. Jeffrey は，最初 Momordica 属植物として分類されていたが，その 後 Thladiantha 属植物に変更され，さらに現在では Siraitia 属植物に分類されている。その果実は羅漢 果と呼ばれ，既に在原らによりその成分研究が行わ れ，甘味成分として mogrosideIV（22）及びV（23） が単離・構造決定されている（Fig. 3).15-17) 同じ Siraitia 属植物のS. siamensis (Craib) C. Jeffrey は 羅漢果の 2 倍程の大きさの果実（翅子羅漢果）をつ ける. 中国雲南省の南部で採集された翅子羅漢果に ついて成分研究を行い，22 及び 23 を単離・同定す るとともに，新規の甘味配糖体 siamenoside- I (51),

11-oxomogloside V（52）（Fig. 8）を単離し，それ らの構造を明らかにした. ${ }^{32)}$

化合物 22 及び 23 以外のククルビタン系トリテル ペン配糖体の検索を目的に羅漢果の成分の再検討を 行い 5 種の配糖体を単離した (Fig. 8). ${ }^{21)} 2$ 種は 51, 52 と同定し， 1 種は新規化合物で mogroside III （28）と命名した。残る 2 種の化合物 $\mathbf{5 3}$ と $\mathbf{5 4}$ は, mogroside V (23) の構造決定の際に得られている マルターゼによる部分加水分解物と一致した. ${ }^{17)}$
これら 7 種の化合物の甘味倍数の測定を行つた結 果，ククルビタン系トリテルペン配糖体の中で最も 甘いとされていた mogroside V （23）（甘味倍数 425）よりも siamenoside- I （51）（甘味倍数 563） の方がさらに甘いことが明らかとなった。化合物 23 は天然甘味料として食品に用いられている。本 系統の甘味物質を得るための有用な資源として，中 国雲南省の昆明植物研究所により本植物の栽培が行 われている。

\section{Neoalsomitra integrifoliola $の$ 配糖体成分}

Neoalsomitra integrifoliola (Cogn.) Hutch は中国 の南部からマレーシアに分布する蔓性の植物であ る。薬としては使用されていない，最初に中国の昆 明植物研究所のグループにより, 塊茎から neoalsoside A（55） と命名されたダマラン系トリテルペン 配糖体が単離・構造決定された（Fig. 9). ${ }^{33)}$ ダマラ ン系トリテルペンの多くは天然には遊離の形で存在 し，配糖体として存在するのは薬用人参，三七人参 などPanax 属植物とウリ科植物のアマチャヅルな どに限られている. ${ }^{34-38}$

その後，われわれとの共同研究で同植物の地上部 から neoalsogenin B（56） と命名した新規の遊離の ダマラン系トリテルペンを 1 種, neoalsoside $\mathrm{A}_{2}$ (57), $\mathrm{A}_{3}(\mathbf{5 8}), \mathrm{A}_{4}(\mathbf{5 9}), \mathrm{A}_{5}(\mathbf{6 0}), \mathrm{C}_{1}(61), \mathrm{C}_{2}$ (62), $\mathrm{D}_{1}(63), \mathrm{E}_{1}(64), \mathrm{F}_{1}(65), \mathrm{G}_{1}(66), \mathrm{H}_{1}$ (67), $\mathrm{I}_{1}(68), \mathrm{I}_{2}(69), \quad \mathrm{J}_{1}(70), \mathrm{K}_{1}(71), \mathrm{L}_{1}$ (72), $M_{1}(73), \quad M_{2}(74), M_{3}(75), N_{1}(76)$, $\mathrm{O}_{1}$ (77)， $\mathrm{O}_{2}$ （78） と命名した 22 種の新規のダマ ラン系トリテルペン配糖体を単離し，それらの構造 を明らかにした（Fig. 9). ${ }^{39,40)}$

化合物 55-67 のアグリコンはオコチロール型側鎖 のダマラン系トリテルペンと呼ばれ，イソプロピル テトラヒドロフラン環を持っている．以降，オコチ ロール型と記載する。人参サポニンのアグリコンで

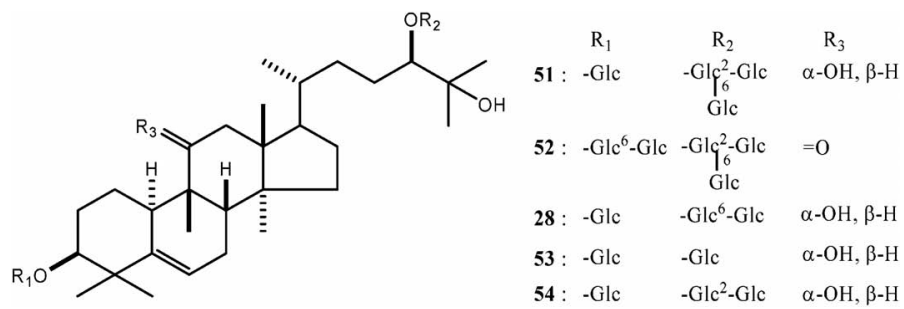

Fig. 8 . 

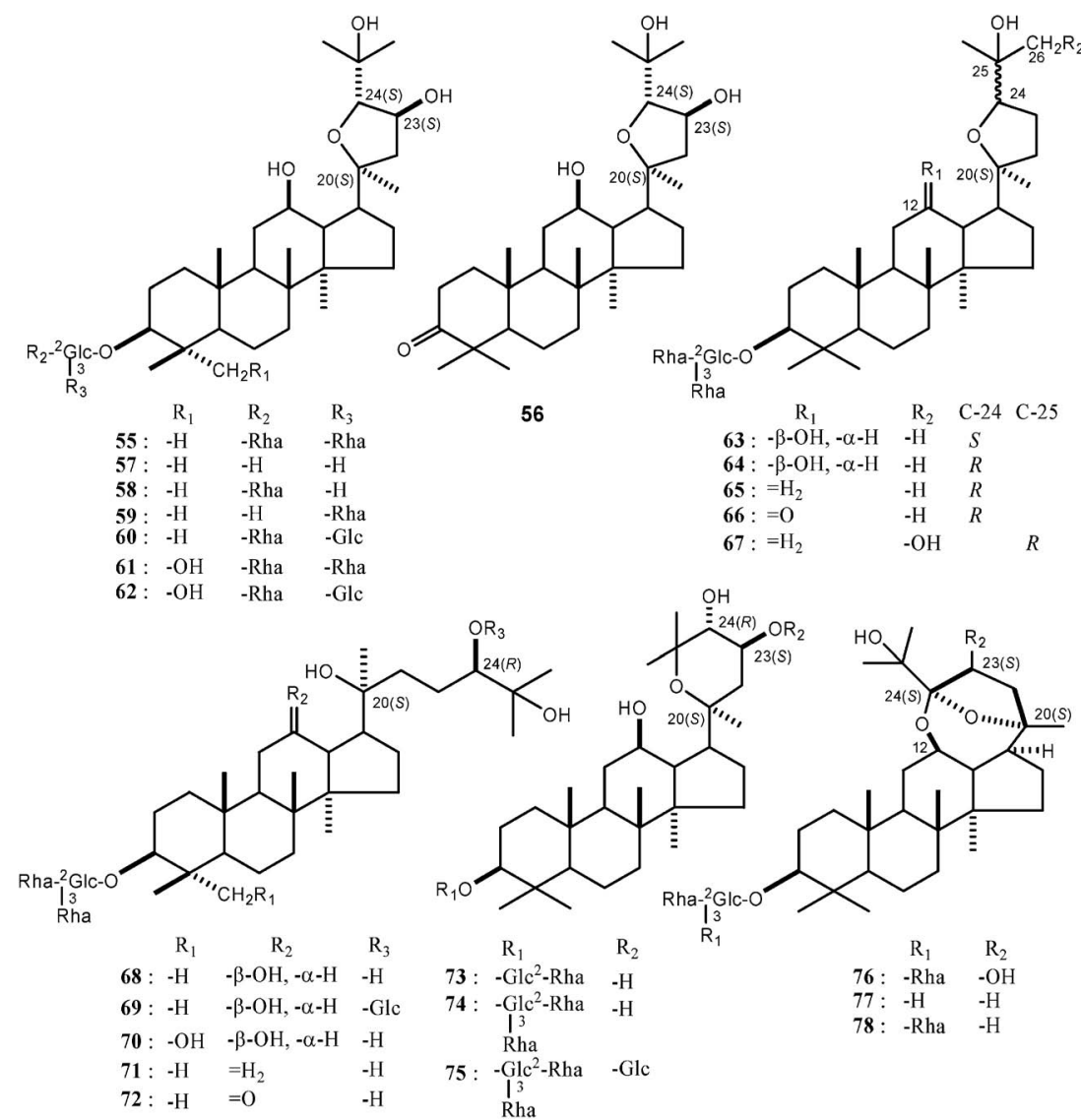

Fig. 9.

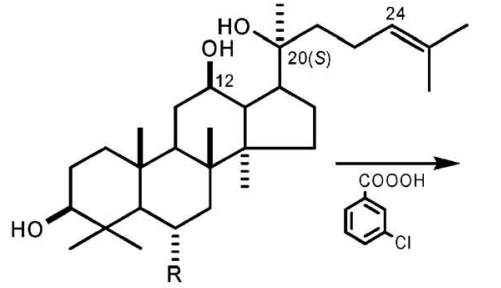

20(S)-protopanaxadiol $(\mathbf{7 9}): \mathrm{R}=\mathrm{H}$ 20(S)-protopanaxatriol $(\mathbf{8 0}): \mathrm{R}=\mathrm{OH}$

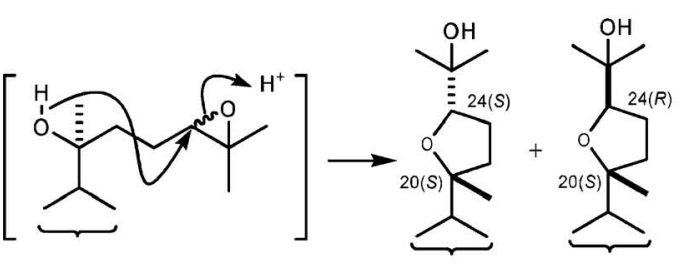

Ocotillol type compounds

Chart 3.

ある $20(S)$-protopanaxadiol（79） や $20(S)$-protopanaxatriol（80）のような 20-hydroxy-24,25-ene 構造を持つものを過酸で処理することで側鎖を容易 にオコチロール型のものに変換することができる.

Chart 3 に示すように，まず 24,25-エポキシ体が生 成し，引き続き 20 位水酸基によるエポキシへの攻 撃により生成するものと推定されている. ${ }^{41)}$ この際 に 24 位の $S$ 体と $R$ 体の混合物が生成する. 化合物 55-67 のうち，互いに 24 位の異性体である 63 と 64 の場合を除き，ほとんどが 24 位異性体のどちらか
一方のみが見い出されており，現在のところ，これ らは二次生成物（artifact）ではないと考えている.

Neoalsoside $M_{1}$ (73), $M_{2}$ (74), $M_{3}$ (75) のア グリコンはテトラヒドロピラン環を持つダマラン系 トリテルペンである. ダマラン系人参サポニンの酸 加水分解（希塩酸）で 20 位の $R$ 体と $S$ 体の混合物 として生ずる二次生成物の panaxadiol や panaxatriol も同様のテトラヒドロピラン環を持つ化合物 である. ${ }^{42)}$ 化合物 73-75 の 20R 体は得られていない ことから，これらについても二次的な生成物ではな 
いと考えている.

構造決定の過程で，アグリコン並びに構成糖を得 る目的で neoalsoside $I_{1}(68)$ の酸加水分解を試みた 際に，オコチロール型化合物 $20 S$ 体（81） と $20 R$ 体（82）の 2 種の化合物が得られた (Chart 4)。こ の反応は前述したような二重結合の過酸による工ポ キシ化反応とは異なるもので，これは予期しない結 果であった。 そこで，他の類似化合物でも，同様の 反応が起きるかどうかを検討した．手元に十分な試 料のあったシラカバから単離した betulafolienetriol （83）を出発物質として，四酸化オスミウムによる 酸化を行い，グリコール体 84 と 85 を得た（Chart
5)。両化合物の C-24 のそれぞれの絶対配置は Eu (fod) ${ }_{3}$ 存在下での CD 測定により確認した. ${ }^{43}$ 化合 物 $84(24 R)$ と $85(24 S)$ を酸で処理することによ り，84 からオコチロール型化合物 $86(20 S ， 24 S)$ と $87(20 R, 24 S), 85$ から $88(20 S, 24 R)$ と 89 $(20 R, 24 R)$ が得られ，この場合も過酸による工ポ キシ化反応と同様な反応の起きることが示された. なお，この環化反応で 24 位が反転している (Chart 5). Betulafolienetriol（83）の過酸酸化によ り化合物 86 と 88 を別途でも合成した.

以上得られたオコチロール型化合物 86-89 は，同 時に neoalsoside $I_{1}(68), I_{2}(69), J_{1}(70), K_{1}$

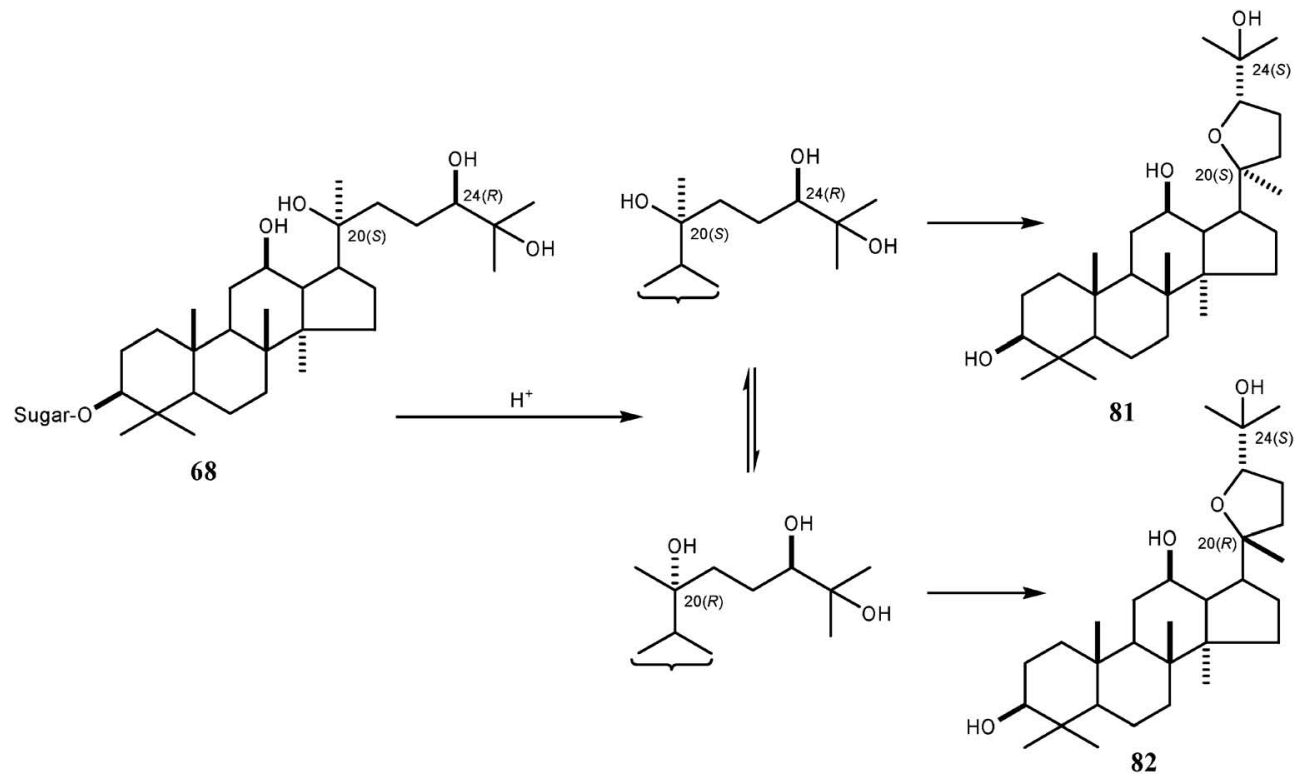

Chart 4.

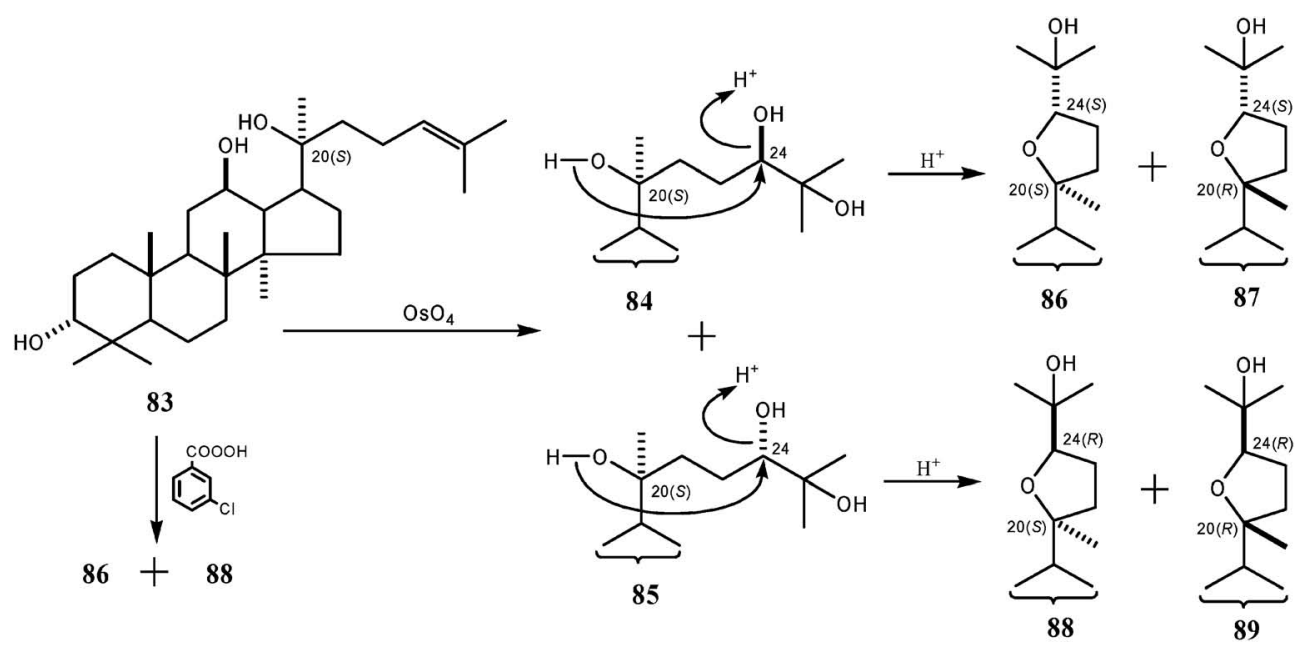

Chart 5 . 
(71)， $\mathrm{L}_{1}$ （72）のアグリコンの 24 位水酸基の絶対 配置を決定するための重要な化合物となった。すな わち，テトラヒドロフラン環及びその周辺の ${ }^{13} \mathrm{C}-\mathrm{NMR}$ シグナルがオコチロール型化合物 $\mathbf{8 1}$ と 86 及び 82 と 87 で完全に一致することから，68の 24 位は $R$ 配置であると決定した。なお，化合物 69 についても 68 と同様である. 化合物 70 及び 72 に ついても同様の実験から 24 位は $R$ 配置であること が明らかとなった。20 位の配置については， betulafolienetriol（83）から得られたグリコール体 84 の $\mathrm{C}-13,16,17,20,21$ の ${ }^{13} \mathrm{C}-\mathrm{NMR}$ シグナルと 一致することから 20 位が $S$ 配置であると決定し た. ${ }^{44)}$ Neoalsoside $J_{1}(\mathbf{7 0}) ， K_{1}(\mathbf{7 1}) ， L_{1}(72)$ に ついても同様に決定した.

われわれは，中国産ウコギ科植物珠子参 [Panax japonicus C. A. Meyer var. major (Burk.) C. Y. Wu et K. M. Feng] の根茎から majonoside R1 (90), majonoside R2（91）と命名したオコチロール型卜 リテルペンのサポニンを単離・構造決定してい る. ${ }^{45)}$ その後, 薬用人参と近縁植物であるべトナム 人参 (Panax vietnamensis $\mathrm{Ha}$ et Grushv.) の地下部

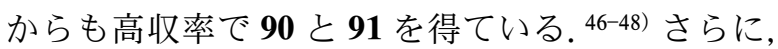
90 と 91 には脳細胞膜の障害により引き起こされる 精神的ストレスを抑制する効果のあることを明らか にしている. ${ }^{49)}$

オコチロール型化合物に関連したものとして，以 下のような研究結果に言及する。 人参サポニンなど ダマラン系サポニンの体内代謝，さらには活性代謝 産物を明らかにする目的で以下のような検討を行っ た. $20(S)$-protopanaxadiol (79) 並びに $20(S)$-protopanaxatriol（80）をラット肝から調製したミクロ ゾーム分画で処理した結果，既に述べた過酸による オコチロール体の生成（Chart 3） と同様の反応

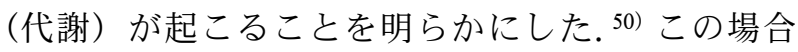
はチトクローム $\mathrm{P}_{450}$ による側鎖二重結合のエポキ シ化に続く閉環反応が起きるものと容易に推測され る. なお， 12 位に水酸基の存在しないダマラン系 トリテルペン，例えば dammarenediol- II （12deoxy-20 (S) -protopanaxadiol) のようなものでは, このようなオコチロール型化合物への変換反応を受 けない。さらに，ダマラン系サポニンを摂取したヒ トの尿中（アルカリ処理後）からもオコチロール型

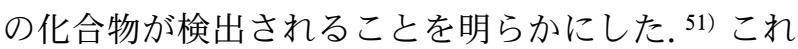

までに人参のダマラン系サポニンの腸内細菌による 糖鎖加水分解などの研究が行われてきたが, ${ }^{52-57)}$ 腸 管からの吸収後の代謝に関する詳しい研究について はこれからの課題である。オコチロール型化合物 が，人参サポニンの体内での活性代謝産物の 1 つで あろうと考えている.

このように，オコチロール型化合物は興味のある 化合物であり，Neoalsomitra integrifoliola はその重 要な資源植物の 1 つである.

\section{Trichosanthes tricuspidata Lour. の配糖体成} 分

タイでは Trichosanthes tricuspidata を解熱剂, 緩下剂，駆虫剂として，あるいは片頭痛を緩和する ための薬として用いている. Figure 10 に示すよう に，この果実から hexanor 型と本系統の化合物と しては非常にめずらしい octanor 型のものを含む 14 種の新規ククルビタン系トリテルペン配糖体 khekadaengoside A-N（92-105）を単離・構造決定 した. ${ }^{58)}$

固形がんの増殖及び腫瘍の転移に血管新生の関与 することが知られている。したがって，血管新生を 抑制する物質が抗がん剂又はそのシード化合物とし ての可能性を持つことになる，さらに，糖尿病性網 膜症にも血管新生が関与していることなど血管新生 抑制剂はがん以外の様々な疾患にも有効であること が示唆されている。ここで単離した配糖体のアグリ コンについて，腫瘍細胞に対する細胞障害活性と血 管新生阻害効果を検討した，以下の生理活性に関す る研究は侏)クルト本社との共同で行ったものであ る.

腫瘍細胞に対する細胞障害活性：腫瘍細胞として 咽頭がん細胞（KB 細胞），肺がん細胞（A549 細 胞），大腸がん細胞（HT29 細胞）を用いた。試料 を入れてない培地で培養したときの細胞数を $100 \%$ として, 細胞数を $50 \%$ に減少させたときの試料濃 度 $\mathrm{IC}_{50}(\mu \mathrm{g} / \mathrm{ml})$ で判定した。 Khekadaengenin II (108) (khekadaengoside D（95）のアグリコン), khekadaengenin III (109) (khekadaengoside E (96) のアグリコン), cucurbitacin J (106), cucurbitacin K (107)， mogrol（110）（khekadaengoside M （104）のアグリコン）について測定し，いずれの細 胞に対しても細胞障害活性が認められ，特に cucurbitacin K（107）に高い活性が認められた. 


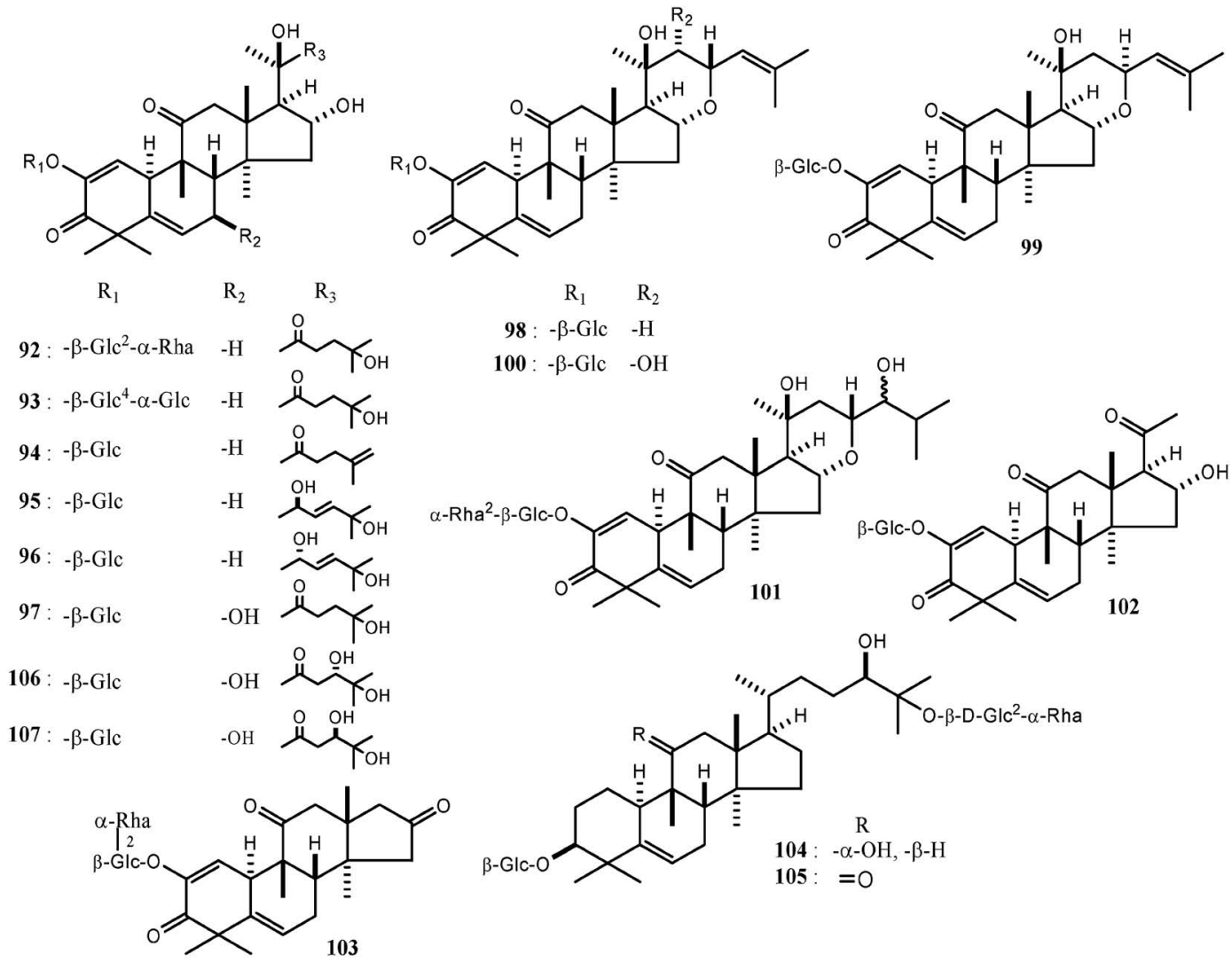

Fig. 10.

血管新生阻害効果（血管内皮細胞増殖阻害活性）： 人臍帯血管内皮細胞（HUVE 細胞）を用いて，培 養したときの各試料の増殖阻害濃度（ $\mathrm{IC}_{50}$ ) を求め た．化合物 106-108 について測定した結果，いずれ も HUVE 細胞の増殖を抑制し，この場合も特に cucurbitacin K（107）に高い効果が認められた。

血管新生阻害効果（血管細胞のキャピラリーネッ トワーク形成阻害活性）：ウシ大動脈血管内皮細胞 （BAE 細胞）を用い，コラーゲンタイプ I ゲル中で のキャピラリーネットワーク（管腔）形成の様子を 調ベた。ネットワークが形成された場合を陰性，形 成されないか形成されても断片的なものは陽性とし た。化合物 106 と 107 について検討した結果，この 場合も cucurbitacin K（107）に高い阻害効果が認 められた。

\section{7. おわりに}

ここに記載した内容は，すべて広島大学医学部総 合薬学科に在職していたときのものです。その間, ご指導ご鞭撻をいただきました故広島大学田中治名 誉教授並びに私の最初の師であり，常に温かく見守 ってくださった做昭和大学庄司順三名誉教授に深謝
いたします．また，研究の遂行に多大なご協力を頂 きました広島大学山㠃和男名誉教授，中国科学院昆 明植物研究所の諸先生, 旭光学侏及びヤクルト侏)の 方々, 広島大学の卒業生の方々に心から感謝いたし ます．以上，昔を思い出しながらまとめさせて頂き ました.このような投稿の機会を与えて下さった関 係者の方々に深謝いたします。

\section{REFERENCES}

1) Kasai R., Yamaguchi H., Tanaka O., J. Chromatog., 407, 205-210 (1987).

2) Kasai R., Miyakoshi M., Matsumoto K., Nie R., Zhou J., Morita T., Tanaka O., Chem. Pharm. Bull., 34, 3974-3977 (1986).

3) Kasai R., Miyakoshi M., Nie R., Zhou J., Matsumoto K., Morita T., Nishi M., Miyahara K., Tanaka O., Phytochemistry, 27, 1439-1446 (1988).

4) Hirai N., Koshimizu K., Phytochemistry, 20 , 1867-1869 (1981).

5) Nakayama K., Fujino H., Kasai R., Mitoma Y., Yata N., Tanaka O., Chem. Pharm. Bull., 
34, 3279-3283 (1986).

6) Nakayama K., Fujino H., Kasai R., Tanaka O., Zhou J., Chem. Pharm. Bull., 34, 22092213 (1986).

7) Watanabe K., Fujino H., Morita T., Kasai R., Tanaka O., Planta Med., 54, 405-409 (1988).

8) Sasaki Y., Mizutani K., Kasai R., Tanaka O., Chem. Pharm. Bull., 36, 3491-3495 (1988).

9) Miyakoshi M., Kasai R., Nishioka M., Ochiai H., Tanaka O., Yakugaku Zasshi, 110, 943949 (1990).

10) Nakagaki M., Arita R., "Seizai Butsurikagaku," Vol. 3, Asakura Syoten, 1968, p. 48 .

11) Encarnacion R., Kenne L., Samuelsson G., Sandberg F., Phytochemistry, 20, 1939-1942 (1981).

12) Nie R., Chen Z., Kasai R., Zhou J., Wu C., Tanaka O., Acta Bot. Yunnanica, 1988 (Supplement I) , 29-37 (1988) .

13) Kasai R., Matsumoto K., Nie R., Morita T., Awazu A., Zhou J., Tanaka O., Phytochemistry, 26, 1371-1376 (1987).

14) Kasai R., Matsumoto K., Nie R., Zhou J., Tanaka O., Chem. Pharm. Bull., 36, 234-243 (1988).

15) Takemoto T., Arihara S., Nakajima T., Okuhira M., Yakugaku Zasshi, 103, 1151-1154 (1983).

16) Takemoto T., Arihara S., Nakajima T., Okuhira M., Yakugaku Zasshi, 103, 1155-1166 (1983).

17) Takemoto T., Arihara S., Nakajima T., Okuhira M., Yakugaku Zasshi, 103, 1167-1173 (1983).

18) Tunmann P., Stapel G., Arch. Pharm. (Weinheim, Ger), 299, 596-597 (1966).

19) Tunmann P., Gerne W., Stapel G., Justus Liebigs Ann. Chem., 694, 162-168 (1966) .

20) Hylands P. J., Kosugi J., Phytochemistry, 21, 1379-1384 (1982)

21) Matsumoto K., Kasai R., Ohtani K., Tanaka O., Chem. Pharm. Bull., 38, 2030-2032 (1990).

22) Cassady J. M., Suffness M., “Anticancer Agents Based on Natural Product Models,' Academic Press (1980).

23) Lavie D., Shvo Y., Gottlieb O. R., Glotter E., J. Org. Chem., 28, 1790-1795 (1963).
24) Melera A., Gut M., Noller C. R., Tetrahedron Lett., 1 (35), 13-18 (1960).

25) Biglino G., Tetrahedron Lett., 4, 1651-1657 (1963).

26) Konoshima T., Takasaki M., Tatsumoto T., Kozuka M., Kasai R., Tanaka O., Nie R., Tokuda H., Nishino H., Iwashima A., Biol. Pharm. Bull., 17, 668-671 (1994).

27) Dinan L., Whiting P., Sarker S. D., Kasai R., Yamasaki K., Cell. Mol. Life Sci., 53, 271-274 (1997).

28) Kubo H., Ohtani K., Kasai R., Yamasaki K., Nie R., Tanaka O., Phytochemistry, 41, 11691174 (1996).

29) Ohsaki A., Kubota T., Asaka Y., Phytochemistry, 29, 1330-1332 (1990).

30) Nie R., Morita T., Kasai R., Zhou J., Wu C., Tanaka O., Planta Med., 50, 322-327 (1984).

31) Kasai R., Tanaka T., Nie R., Miyakoshi M., Zhou J., Tanaka O., Chem. Pharm. Bull., 38, 1320-1322 (1990).

32) Kasai R., Nie R., Nashi K., Ohtani K., Zhou J., Tao G., Tanaka O., Agric. Biol. Chem., 53, 3347-3349 (1989).

33) Chiu M., Nie R., Nagasawa H., Isogai A., Zhou J., Suzuki A., Phytochemistry, 31, 2451-2453 (1992).

34) Tanaka O., Kasai R., "Progress in the Chemistry of Organic Natural Products, Vol. 46", eds. by Herz W., Griesbuch H., Kirk G. W., Tamm C.h., Springer-Verlag, Vienna, New York, 1984, pp. 1-76.

35) Takemoto T., Arihara S., Nakajima T., Okuhira M., Yakugaku Zasshi, 103, 173-185 (1983).

36) Takemoto T., Arihara S., Nakajima T., Okuhira M., Yakugaku Zasshi, 103, 1015-1023 (1983).

37) Takemoto T., Arihara S., Yoshikawa K., Nakajima T., Okuhira M., Yakugaku Zasshi, 104, 325-331 (1984).

38) Yoshikawa K., Arimitsu M., Kishi K., Takemoto T., Arihara S., Yakugaku Zasshi, 107, 361-366 (1987).

39) Fujita S., Kasai R., Ohtani K., Yamasaki K., Chiu M., Nie R., Tanaka O., Phytochemistry, 38, 465-472 (1995).

40) Fujita S., Kasai R., Ohtani K., Yamasaki K., Chiu M., Nie R., Tanaka O., Phytochemistry, 
39, 591-602 (1995).

41) Nagai M., Tanaka N., Tanaka O., Ichikawa S., Chem. Pharm. Bull., 21, 2061-2065 (1973).

42) Shibata S., Fujita M., Itokawa H., Tanaka O., Ishii T., Chem. Pharm. Bull., 11, 759-761 (1963).

43) Partridge J. J., Toome V., Uskokovic M. R., J. Am. Chem. Soc., 98, 3739-3741 (1976) .

44) Asakawa J., Kasai R., Yamasaki K., Tanaka O., Tetrahedron, 33, 1935-1939 (1977).

45) Morita T., Kasai R., Tanaka O., Zhou J., Yang T., Shoji J., Chem. Pharm. Bull., 30, 4341-4346 (1982).

46) Nguyen M., Nguyen T., Kasai R., Ito A., Yamasaki K., Tanaka O., Chem. Pharm. Bull., 41, 2010-2014 (1993).

47) Nguyen M., Kasai R., Ohtani K., Ito A., Nguyen T., Yamasaki K., Tanaka O., Chem. Pharm. Bull., 42, 115-122 (1994).

48) Nguyen M., Kasai R., Ohtani K., Ito A., Nguyen T., Yamasaki K., Tanaka O., Chem. Pharm. Bull., 42, 634-640 (1994).

49) Yobimoto K., Matsumoto K., Nguyen T.,
Kasai R., Yamasaki K., Watanabe H., Pharmacol. Biochem. Behav., 66, 661-665 (2000).

50) Kasai R., Hara K., Dokan R., Suzuki N., Mizutare T., Yoshihara S., Yamasaki K., Chem. Pharm. Bull., 48, 1226-1227 (2000).

51) Matsuura H., Udayama M., Dokan R., Kasai R., Yamasaki K., Tanaka O., Nat. Med., 56, 34-39 (2002)

52) Odani T., Tanizawa H., Takino Y., Chem. Pharm. Bull., 31, 292-298 (1983).

53) Odani T., Tanizawa H., Takino Y., Chem. Pharm. Bull., 31, 1059-1066 (1983).

54) Odani T., Tanizawa H., Takino Y., Chem. Pharm. Bull., 31, 3691-3697 (1983).

55) Karikura M., Miyase T., Tanizawa H., Taniyama T., Takino Y., Chem. Pharm. Bull., 39, 2357-2361 (1991).

56) Hasegawa H., Uchiyama M., Planta Med., 64, 696-700 (1998).

57) Akao T., Kida H., Kanaoka M., Hattori M., Kobayashi K., J. Pharm. Pharmacol., 50, 1155-1160 (1998).

58) Kanchanapoom T., Kasai R., Yamasaki K., Phytochemistry, 59, 215-228 (2002). 